\title{
C'est Passionnant d'être Passionné
}

by

\section{William J. Samarin}

Department of Anthropology, University of Toronto, Emeritus

A memoir of my life as a linguist

To appear in

First Person Singular III

(IN PREPARATION)

Studies in the History of Language Sciences, 62

Edited by Konrad Koerner

Amsterdam and Philadelphia: John Benjamins Publishing Company

(- William J. Samarin, 1995.

Not to be duplicated, circulated, cited, or used in any way without written authorization. 


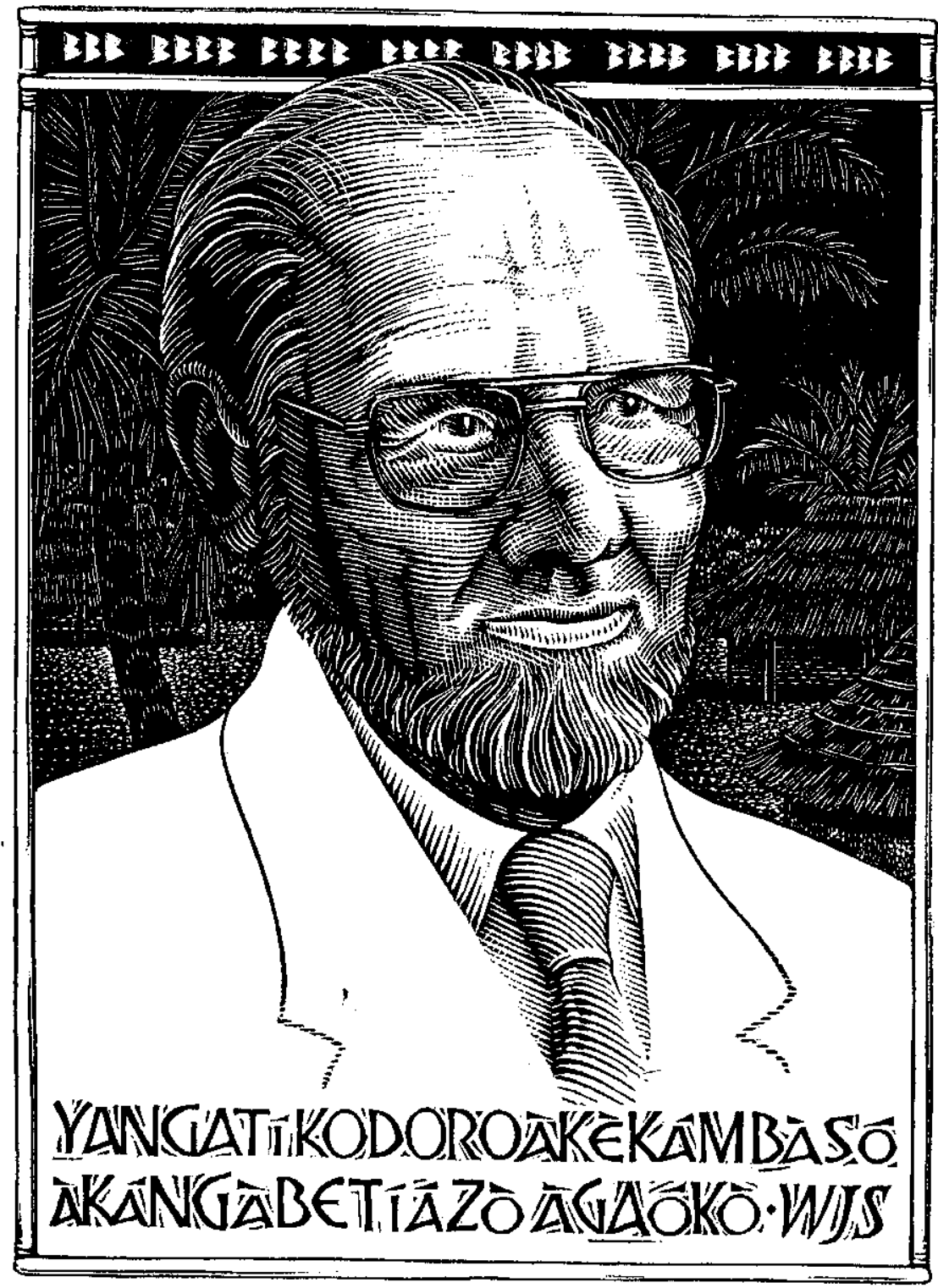





\title{
C'est Passionnant d'être Passionné ${ }^{1}$
}

\author{
William J. Samarin \\ University of Toronto, Toronto, Ontario, Canada
}

\section{The Beginning}

My wife tells me, without any antipathy to linguistics, that I should have been a chef de cuisine or an interior decorator. Yes, I might have enjoyed being one or the other, but they were not what I had considered in my youth. The first careers were suggested to me by my father, when I was still in primary or junior high school: becoming a physician or lawyer. But when I was just fifteen years old, I chose to go into some type of Christian ministry.

In our ethnic community - rather densely congregated in neighborhoods just east of the Los Angeles River in Los Angeles, California, first in what the locals called 'Flats,' being the land that used to be flooded by the river, and subsequently to the then-nicer area of Boyle Heights, up the hill eastward - that was a goal as strange and foolish as being a chef or interior decorator would have been. (Some of the most successful men among our people were collectors of industrial rubbish.) Molokans after all have no clergy, just self-supporting elders elected for life (Young 1932).

That adolescent's decision was the set of the sail that sent me from what used to be called the colony (translated from the Russian) to lands, vistas, and experiences foreign to my peasant ancestry. Joyce Carol Oates seems to be correct in her observation about American life (1995:36): "Where we come from in America no longer signifies - it's where we go, and what we do when we get there, that tells us who we are."

My wife was not around when I was making early decisions, and she made that remark (on more than one occasion) only after our marriage and before she knew that as an adolescent I used to collect recipes published in the Saturday edition of the Los Angeles Examiner, even though there was no possibility of experimenting with any of them, given the fact that my father would not deviate from the community's 'kosher' cuisine. Nor did she know that for a while I collected pictures of houses from the real estate section of the paper. In any case, I came to understand later that I liked architecture or any form of art dominated by linear composition, a predilection that is revealed in my photography. Visual art may even be a

\footnotetext{
' If my family does not approve using these words for my epitaph, let them be recognized retroactively as the slogan of my linguistic career: for example, "Field work is characterized in one word ..; it is fun" (Samarin 1967:vii). The phrase in my title, however, was discovered only in 1994, while improving my French by reading advertisements at train stations we were stopping at or passing by. (I was so captivated by the words that I failed to see what was being advertised.) The words can, of course, be 'translated' in one of its senses for the person who is not familiar with French: 'It's fun being enthused' (in colloquial English).
} 
metaphor or analog of the linearity manifested in the argumentation of a scholarly essay, at least, the kind I admired as 'Bloomfieldian' and later discovered as Aristotelian. In any case, I feel esthetically about scientific exposition as I do about neatness and simplicity. My parents tell me that by the time I reached the kitchen in the back of the house after entering the front door, as a child and adolescent (the eldest of seven children), everything would be in order. I feel best when my environment, outside as well as inside, is uncluttered. I have always been a clean-desk man. Our house, as my mother would say, is "'maculate." It is quite possible, therefore, that science for me is as much a way of putting things in order as it is a means to provide me with adventures in discovery, which is not to say that orderliness is requisite in science, as I see from some of my illustrious friends and acquaintance.

If from my mother's family, the Kornoffs (an anglicization and abbreviation of a four-syllable name), I inherited both an enthusiastic and boisterous manner of speaking and an artistic sensibility, although Mother with too many children had time only for crocheting and tending a few plants outdoors, it was from my father, a somber Samarin, that I inherited my inquisitiveness. Because he had no education and had to support a large family through the Great Depression, this was never developed in a formal way. Here is an example I observed on a long trip in California he had made before: he quietly calculated how much mileage he could save by 'cutting the corners' of the highway on turns. This attention to details made him the fastest broom-maker in Southern California: twenty-nine to thirty-two dozen brooms a day. Father, however, was not a model for neatness and orderliness.

From my mother also I must have inherited an appreciation of the exotic. This trait, however, was not allowed to flourish in an ethnic community where the United States was divided between 'us' Russians and 'them' Americans. But of the few girls during my high-school years I was interested in, and only at a distance (being a pimply, very shy, stammering, bookish, and introverted young man), one was Tomoko, a quiet, studious Japanese-American, and the other Kathleen, a cute, light-skinned African-American. (Theodore Roosevelt High School was the most cosmopolitan of all the high schools in the city, and this fact was enjoyably celebrated on our annual International Day.) Unlike my father, who dealt in business transactions with any kind of a person when peddling brooms - speaking over a fence of ethnic distinctiveness, so to speak my mother seemed to be oblivious to ethnic distinctions in spite of the community's sanctions against unnecessary fraternization with outsiders for fear of exogamous marriages among the young.

In this social and familial context there was little opportunity to encounter and experience the exotic except through reading and eating (always clandestinely) Mexican and Chinese food ('kosher' I always hoped!). My father for years teased me about having almost turned into an Eskimo when I learned about them in grammar school. The Greeks were my heroes, and like so many others more advantaged than I, I also discovered novels by James Fenimore Cooper, Victor Hugo, Alexandre Dumas, and many other classics for children and young people. How this happened in a community in whose homes one never saw reading material either in Russian or English (nothing but an opened Russian Bible, prayer book, and song book on the dining-room table, the 'altar' of every home), I do not know. Children, moreover, 
were not allowed a lot of free time: there were always household chores; even better was a job that could add to the family's income. My several jobs included peddling brooms from door to door in residential areas and in grocery stores all over the city (on foot, of course), selling ice cream in a cart that I pushed around the city, and newspapers at the corner of Seventh and Mateo streets in the industrial neighborhood on the west side of the Los Angeles River.

Many people in our community actually believed that too much studying was bad for the brain. (Molokans excelled in sports, not in academics. Therefore, in spite of my father's having mentioned a career as a professional of some type, possibly only on one occasion, there was no encouragement or praise for excellence in our family.) Reading, nevertheless, was a passion: I read even as I walked to school and at every opportunity during school hours. A really marginal person was I in coexisting but disparate societies. On occasion I had lonely adventures in the expansive empty lots of an industrial area in 'Flats,' where horned toads and lizards abounded. These were also Elysian fields for boys who wanted to do battle in friendly gangs, very different from those now dominating their 'turfs' where housing projects have obliterated most of my childhood's landmarks.

Objectivity and criticality were qualities for which I seem also to have been programed. Education during the Depression and World War Two was not very good in Boyle Heights. Nonetheless, by the time I was eighteen I had my own ideas about life as a Molokan from asking questions and observing the behavior of others in our ethnic grocery stores, bakeries, butcher shops, and the religious services I was obliged to attend.

There was, for example, a 'young people's church' where adolescents were encouraged to participate in Molokan services patterned after the adult ones, and where they learned prayers and songs in Russian. It was nick-named Chulok ('stocking') for a reason I never discovered, and was entered through an alley off of Utah Street. Parents liked their children to go there, of course, because of the marriages that might follow friendships. I went there - not for the girls, to tell the truth, but - to observe: I was no longer a Molokan at heart. I noticed the way young people, especially girls, were influenced into being 'filled with the Holy Spirit.' (This Russian sect was 'Pentecostal' in Russia before Pentecostalism arose in the United States.) The influence was through music, sung without musical instruments; music with a strong beat, designed for a kind of jumping or dancing 'in the Spirit.' The floor of uncovered pine planks was a perfect percussionist tool for Fred Hazen, who led the men's choir and was one of the adult leaders of the church. Again and again I went home to make ethnographic notes about what I saw: for example, about how, having increased the pace of the beat and changed the pitch in ways I did not understand, he would strike the floor vigorously with one large foot, uttering a single unintelligible cry. At that instant people were 'filled with the Holy Spirit,' some to gyrate and careen in the center of the small church in a state of dissociation. (My fledgling anthropological notes from this period were lost in a fire.)

Science had obviously been of interest to me. Not chemistry, however; and I can't remember if I had any physics in high school, but I enjoyed physiology: I mastered the book that was available in the classroom. For that reason, perhaps, I did so well in zoology in my first term 
as an undergraduate that the chairman of the zoology department invited me to major in the subject.

\section{The Middle: Language}

Where was language at this time?

A 'foreign' language was in my intimate environment. Russian was the dominant language of all those in my parents' generation, who had arrived in the United States with their parents and grandparents as young children. Even an African-American adolescent girl of my mother's generation learned Russian from her playmates. My knowledge of the language, however, was only passive, since my mother spoke to me in English; Father in Russian and broken English. He taught me to read in Russian. I also memorized songs, prayers, and Scripture portions. With my grandparents and paternal great-grandparents I could not carry on the conversations I would certainly have enjoyed. The first foreign language I set myself to learn was Spanish. (Only Spanish and Latin were taught at Stevenson Junior High School.) Could Mr. Heslett, one of the few names of teachers I recollect and whose joyousness made learning a language fun, have contributed a bit to the direction in which I was to go? In any case, I did well enough to continue with Spanish in high school, where French was considered a sissy's language.

It was at this time that I realized that there was an English that was foreign to me. When I was to make a speech at the graduation service in 1941, a teacher-coach pointed out to me that I said dis for this, wit for with, since like most of us in our community I had not learned to produce interdental fricatives. Also at this time I had the pleasure of using a newly discovered syntactic construction in signing autograph books on graduation day. From this time on I tried to speak and write good English, even though I began to speak differently from my peers, like 'pronouncing my $t$ 's' between vowels! However, for years after people continued to ask about my accent and what foreign country I had come from. Even today I seem to speak other languages with a Russian accent. I learned this when it was pointed out to me by two different French-nationalized Russians with whom I was speaking in French. A knowledgeable person might detect a Russo-American accent also when I speak in Gbeya, Sango, and Portuguese.

The analysis of English attracted me in high school. We did what was called diagramming sentences (see H. A. Gleason, Jr.'s Linguistics and English Grammar [1965]). I must have done well in the class, because the teacher favored me when I ran for the office of student body president.

The war notwithstanding, I prepared myself for the ministry. I had to discontinue undergraduate studies in 1944, and begin studying in a four-year Bible school closer to home. (That story is a long one.) I was an odd student at this rather fundamentalist, downtown school in Los Angeles: When I enrolled I was reading Charles Darwin's Origin of Species. This and other books I read were not in the library or, if they were, were marked as having been 'indexed.' It was here that I found further pleasure in language, enjoying the study of koiné (New Testament) Greek, to which I added classical Greek in university, with Murray B. Emeneau (Emeneau 1994), 
as I recall.

At this very Bible school - of all places imaginable! - I was introduced to linguistics but not a career as linguist. In my fourth and final year I took a one-semester, elective night-course in phonetics with Kenneth L. Pike, motivated by what I had heard about what the Summer Institute of Linguistics was trying to accomplish in the world through its affiliated organization, Wycliffe Bible Translators. Pike was in Southern California, on leave from the University of Michigan, when he was translating the New Testament into Mixtec, a language spoken in southwestern Mexico. This was 1947 . He did not, as he never did to my knowledge, accommodate himself easily to the ignorance of his audience. (For an interview with Pike see Kaye 1994.) By this time we decided, my fiancée and I, to take SIL's summer course at the University of Oklahoma, both of us hospitable to the idea of becoming Bible translators with SIL. ${ }^{2}$ Pike lectured on phonetics and phonemics with the zeal and seriousness of a prophet and Eugene A. Nida both on morphology and syntax and also on anthropology, no less fascinating for being taught with wit and humor (Nida 1991). (Through all my younger days Nida was a faithful and helpful kóyà 'maternal uncle,' noted for, among other things, never failing to reply to a letter and doing that promptly). ${ }^{3}$ All the laboratory sessions and tutorials were conducted by 'members,' as they call themselves, of SIL. These teaching assistants, all of whom had had field experience, mostly in Mexico, were devoted to their tasks and were excellent pedagogues: the training in phonetics was superb, arguably the best that one could get in North America at that time. Moreover, we profited from lectures by guest speakers such as George L. Trager and Paul Garvin. During the eleven-week session I had my first field experience, working on Comanche for ten days with an informant. (This was an obligatory part of SIL's summer session.)

But being a member of SIL, my wife-to-be and I decided, was not what we wanted. The ironic thing is that the principal reason was that SIL's work, as presented by K. L. Pike in a lecture to prospective candidates, did not appear to have the combination of evangelistic and linguistic ministries of which we had formulated for ourselves a certain model. ${ }^{4}$ However, we,

2 The courtship took place while we were students at Bible school. The marriage was strongly opposed by my parents, because she was not a Molokan, and considered ill-advised by my future mother-in-law, because I was not 'Anglo' enough! (Or was I not yet enough of an 'American' as Ruth's father, Fernando Varela da Costa, an immigrant from Portugal?) My wife has found the learning of languages disagreeable and has been only a spectator to my enthusiasms. In Africa her principal role was that of teacher. As the wife of an academic she was handicapped by dyslexia in participating in any way as a collaborator in my work, a practice more common than academic history has hitherto sufficiently documented. More important was keeping me alive (for which see below).

3 William Smalley once informed me that Nida kept a file of anecdotes and jokes for his public lectures. The one I remember was what a missionary among the Ituri pygmies told an anthropologist: "You're concerned about the cULTURE of these people; we care about their sours." Her husband was a classmate of mine in Bible school.

4 Although I never maintained any kind of relationship with SIL as an organization during my linguistic career, I kept informed about the activities of many of its members, not only through their publications but also in private correspondence. My wife and I also contributed financially to the support of one family of SIL members for a number of years. In 1964, when SIL had just begun its work in Africa, I was invited to give a seminar on African linguistics at the summer school at the University of Oklahoma. 
or at least I, had acquired the passion for linguistics, and we agreed on the goal of using this science somewhere in the world in a practical way. More education was needed.

Some time between 1947 and 1950 my wife and I decided to serve in Africa after having corresponded with several missionary societies. We had even considered serving in Brazil (and had taken a course in Portuguese at the University of California at Berkeley), but the Brethren (see below) were not planning a work among the indigenous peoples there.

There was no department of linguistics at the University of California, at Berkeley, where I had decided to study in 1947, but Murray Emeneau, in the Classics Department at that time, to whom I had been sent (I don't remember by whom), said that a group major could be arranged. ${ }^{5}$ My minor was in anthropology, to which I had been introduced in Bible school, where it was taught by a candidate for a doctorate in philosophy at the University of Southern California, Bernard Ramm, one of the best teachers I ever had, who taught with authority, gentleness, and wit; our textbook was Peter Murdock's Our Primitive Contemporaries. This work made us acutely aware of cultural differences. Ramm's purpose was to make his students reflect on how they would react to these differences as agents in the spread of Christianity (stated in my words, of course). From him I also took Biblical Hermeneutics, not too different a task from what I eventually learned was critical reading of scholarly texts. ${ }^{6}$ At Berkeley I also took whatever courses I could find on Africa and Islamic civilization. Emeneau taught morphology, using Nida's revised volume (Nida 1949). Harold Conklin, a classmate, who already had made a significant study of the Hanuno'o of the Philippines while in the army, was my collaborator in the early hours of the morning as we occasionally worked by telephone on the long and difficult problems, he in some building belonging to the Department of Anthropology, where he was working on his dictionary of Hanuno'o, and I at home. He was later to be my sponsor when I applied for membership (i.e., as Fellow) in the American Anthropological Association. Eugene Hammel, who also went into anthropology and later became an equally distinguished teacher at his alma mater, was another friend and classmate in linguistics (and the one who nominated me for membership in the Phi Beta Kappa association). There were others in my classes, like William Bright and William Sturtevant, but I did not get personally acquainted with them, being married, and still awkward in 'American' society. Bright has corrected my erroneous claim in a personal communication that $I$ was the first person to receive, in 1950, a B.A. in linguistics (see Murray 1994:297fn); he had received his with an 'individual (or, group) major' the preceding year. And even he may have been

\footnotetext{
5 The first appearance of a Linguistics Department at the university with its own courses is in the catalog of 1953-1954, but there is no mention that an undergraduate major was possible (personal communication, Stephen $O$. Murray, 22 September 1995).

6 Thus a professor of Hebrew and Old Testament has written: "I find it difficult to engage theological presentations that have not been purged through the fire of careful exegesis. .. True theology and precise exegesis are, to use modern jargon, systemically dependent upon one another" (Waltke 1993:11), a position taken over one thousand years ago by Jewish scholars. It is careful reading that leads me to conclude that in the following ostensibly scientific statement is the use of the ancient persuasive device of 'magnification": "the sexual differentiation of speech often plays a major role in the mechanism of linguistic evolution" (Labov 1972:303); see Aristotle, Rhetoric 1.7. Emphasis has been added in both quotations.
} 
preceded by Oscar Chevarria-Aguilar, who, like me majored (as one says in North America) in linguistics and anthropology. In any case, the official transcript of my records reveals that I was "Allowed to adopt individual grp [group] major in Linguistics," and my B.A. diploma reads "Highest Honors in Linguistics."

The courses in linguistics and anthropology I took as an undergraduate comprise thirty-six of the ninety-four units I earned at Berkeley, the rest of the 124 coming from Wheaton College, Wheaton, Illinois and the University of Oklahoma, which granted credits for courses taken at the Summer Institute of Linguistics: ${ }^{7}$

$\begin{array}{lll}\text { Anthropology } & 7 \text { courses } & 24 \text { units } \\ \text { Oriental Languages } & 3 \text { courses } & 10 \text { units } \\ \text { Classics } & 1 \text { course } & 2 \text { units }\end{array}$

The ones in Oriental Languages were taught by Mary Haas and the one in Classics, which was Morphology, by Emeneau. It seems to me now that material in three of the four courses in linguistics had been covered at the summer institute in 1947.

Mary Haas, who taught Phonetics and Phonemics, Field Methods, and Types of Linguistic Structures, was an accessible professor who would join us when braver students than myself, like genial Gene Hammel, invited her for coffee after class. (Our venue, being on the university's land, long ago disappeared with the growth of the university.) As many of her students have testified, she was an encouraging teacher who did not wait for requests to help her students. (For the tributes of others, see Shipley 1988.) One day, for example, she asked if I would like to work on an African language as an extracurricular activity; she (with research funds, I suppose) would pay for the informant. That is how I got to work on Kisi, a Liberian language (1952b). Haas would drop by occasionally, where I was working in the Hearst museum building, a sort of barn constructed of galvanized iron sheets.

The study of language has developed in an awesome manner since $I$ was first introduced to it. The first textbooks on linguistic analysis were just beginning to be written by Eugene A. Nida and Kenneth L. Pike. (In 1947 we used their mimeographed versions, and in 1951 Nida's on syntax that was never published commercially.) Of course, we all read Leonard Bloomfield's Language and Edward J. Sapir's book by the same name. The latter was assigned reading in Language and Culture, taught by John Rowe, an archeologist in the Department of Anthropology. If one read Language, the International Journal of American Linguistics, and Word, one could (one thought as a conscientious student in the United States) be rather well-informed about the field. I refer to 'the study of language' and not linguistics, because language has come to be studied in so many different ways. What have become vast streams of

\footnotetext{
${ }^{7}$ The registrar at the University of California at first refused to transfer credits from Oklahoma. When I went to see him to appeal my case, he explained that credits from a midwestem university were not recognized. Only after explaining to him that the textbooks for linguistics used on the UCB campus were written by the teachers with whom I had taken courses did he grant my request.
} 
subdisciplines were not yet in existence or were just rivulets trickling through the forest of scholarship hardly noticed at all. Linguistics, one felt, was the study of language in all kinds of ways, and descriptive linguistics was just one of these ways, because its goal was to describe languages.

In the fall of 1950 I undertook another linguistic study whose motivation recurred in later years. There is one Protestant denomination that insists that baptism must consist of three immersions, gestural but divinely ordained icons, one might say in contemporary language, of the repetition of the Greek word kai in the formula "in the name of the Father and of the Son, and of the Holy Spirit." On my day off as assistant pastor (a gratuitous title) in one of its churches, I collected data from the New Testament, writing every datum on a separate piece of paper. I sought to establish that this literalistic interpretation was based on a misunderstanding of the style and syntactic structure of Greek, a study that led to a publication in the journal that had just been launched by the United Bible Societies, to which Nida contributed importantly (1952a, the title of which already reveals my predilection for alliteration!). (This kind of skepticism was alluded to above. Thirty-some years later, unhappy about what appeared to me to be off-the-cuff allegations by two colleagues about the origin of Chinook Jargon, I undertook an investigation which took up much of my time for three years and for which I had no qualifications other than having become an autodidactic historian in researching the origins of Sango, Lingala, and Kituba [1986, $1988,1995]$.) In addition to the study of Greek syntax at that time I undertook something more exotic. I collected words and phrases in Armenian from a member of the church who was a survivor of the Armenian Holocaust in Turkey after the First World War. Obviously, the linguistic training I had had as an undergraduate had fertilized a zeal for the study of languages. I had become passionné.

This was my only experience as a cleric (or quasi-cleric, since I was not yet ordained) in the United States and the first as a 'professional linguist,' for one of my duties was teaching Spanish in the church's private high school, where I was able to bring my acquired knowledge of, and enthusiasm for, linguistics into the classroom. However, demanding then, as I have always been as a teacher, I failed too high a number of students!

Advanced work in linguistics was begun at SIL's summer institute at the University of Oklahoma in 1951. Students were now being indoctrinated with tagmemics, which K. L. Pike had invented and was teaching at that time. There was, however, a diffident dissident: Richard Pittman, a member of SIL, with whom I took a course. He was still working on his Ph.D. under Zellig S. Harris at the University of Pennsylvania (Pittman 1953; on Harris see Nevin 1992.) What I remember about that summer, however, was working on Kiowa, another tone language which prepared me for Africa. (At that time, as I recall, all the language informants were American Indians.) I do not remember whether or not all of us were required to devote the whole summer to a single language, but I did. Eugene Nida financed my work, because, being the generous and philanthropic person he is, he wanted the Kiowa to have a primer in their language. My job was not to prepare the primer but to analyze the language. And what a difficult language it was for a neophyte in Amerindian languages! (I left all the data and analyses with SIL, 
annonymously, I suppose, but see Merrifield 1958. ${ }^{8}$ Preparing to go to Africa, I naturally read all I could on African languages, surprised at how little had been learned about tone, since Pike had given us a good introduction to the subject in Amerindian languages and almost all the other teachers and teaching assistants had had experience with tone languages. My 'term paper' was on intonation in tone languages $(1952 \mathrm{c})$.

Serving in Oubangui-Chari (now the Central African Republic), where my wife and I had by this time decided to go, required learning French, with which I had made only an acquaintance at Berkeley. We spent nine months in France, where we studied at the Alliance Française and the Sorbonne. As soon as I could manage to read fairly well, I spent one afternoon a week in the library of the Musée de l'Homme, reading about the area to which we were going. For the same purpose in February 1952 I made a trip to the School of Oriental and African Studies in London to work in the library. Pike had recently been in England to investigate the possibility of founding one of SIL's summer schools there. Malcolm Guthrie, chairman of the School, surprised me by expressing his disbelief in the phoneme. After American linguistics, confident with what I had learned and perhaps arrogant with the ignorance of youth, I found people at the School rather antedeluvian. More uninformed about linguistics - but understandably so, given the relative novelty of linguistics - was Rev. William J. Bradnock, Nida's counterpart as Secretary of Translations, whom I went to see about the translation policies of the British and Foreign Bible Society, which was responsible for translation in the part Africa to which we were going. France also appeared to me uncultivated with linguistics: African languages had not been or were being studied to the same degree as in England; 'modern linguistics,' as I knew it then, was unknown. Ignorant of all the French linguists I might have met in Paris, I had a conversation only with André-Georges Haudricourt (for a reason I cannot remember, since he was not an Africanist) and Lilias Homburger, the only Africanist I knew of (Homburger 1949). ${ }^{9}$ Our rendez-vous took place in her high-ceilinged apartment. We probably spoke in English, but I cannot remember what we talked about except that I passed on to her some kind words Pike had made about her to me.

Being in Paris gave me the opportunity, of course, of improving on my linguistic armamentarium by browsing in the bookstores of the Sixième Arrondissement, something I had done in London as well. I bought books by Père Calloc'h and Père Tisserant on Sango and other ethnic languages of Oubangui-Chari. I had already shipped my library to Bangui. (Remnants of books on anthropology, which I had later given to a missionary colleague also interested in anthropology, were still in existence in 1994.) The journals to which I subscribed were the following, showing the years in which my subscriptions began:

${ }^{8}$ Merrifield acknowledges the contributions of his predecessors: "Since Kiowa has served as a laboratory language for the advanced course of the Summer Institute of Linguistics since 1950, many students and staff hours have been spent in amassing Kiowa data and in carrying forward its analysis" (1958:168, fn 3).

9 Among the many things I regret is that I made no attempt to keep in touch with Haudricourt, for he became a very-much respected scholar in France, and although he specialized in languages in the Pacific, he was what we in North America would call an anthropological linguist. 
International Joumal of American Linguistics, 1950

African Abstracts, published by the International African Institute, 1950

Language, $1952^{10}$

African Studies, published by the University of the Witwatersrand, 1952

Word, the Linguistic Circle of New York, 1953

However, I did not find the works on Sango of much use, except that from one dictionary I learned the phrase ngu $t i$ wa (water of fire) for 'hot water,' uttered to a boy (domestic servant) in that pidgin fashion - a noun phrase and nothing more - on the morning after our arrival in Bangui, because I wanted to shave. The disciplined acquisition of Sango was to take place at the mission's Bible school taught in Sango, seven kilometers from Bozoum. ${ }^{11}$ There is where I began, at last. From one of the students who knew a little French I elicited 'How do you say ...?' The rest of learning Sango was virtually a monolingual process (which I had seen Pike demonstrate in Oklahoma), even though the New Testament was available, which I deliberately avoided, wanting to learn an African, not missionary, variety of the language. Fortunately, the missionary assigned to teach us Sango believed that the language was so simple anyone could easily learn it. After only an hour, he left us with the Scripture as our textbook. Tones were not marked, because no one had realized the role of tone in the language. (Even the British, I had learned, did not understand the phonemicity of tone in African languages.) I, however, had arrived with a different expectation. With Pike's technique of using frames with constant tone (Pike 1947), I set to work on learning to speak Sango as no white person had ever done before. All tones proved to be constant, fortunately: I could use $n \dot{a}$, a general preposition, for low tone; $t \dot{t}$ 'of' and $n i$ a determinant, for high tone. There was also a mid tone, but I was frustrated by being unable to find consistency in its use between speakers, not realizing that my Gbaya, Kaba, Kanre, Suma, and Gbanu informants spoke languages some of which have two register tones and others three! (Although not rectified in my grammar of 1967 , I have been marking the tones according to what I find in Bangui.)

From these students, out of curiousity, I collected vocabularies, using Morris Swadesh's list for glottochronology. (Lexicostatistics was the rage of the time.) And I continued this kind of data collecting when we were assigned, much to my disappointment and consternation, to an area where we were to work in Sango, not an ethnic language. Mbaiki, where we arrived in January 1953, is at the northern fringe of Bantu languages in the Central African Republic; its local language is Mbati (also called Isungu). Nearby on the Lobaye River was Bangandu, another Bantu language, and toward the Ubangi River I found Ngbaka (identified by linguists as Ngbaka-Ma'bo) and Monzombo, these latter two Ubangian languages. I tried to learn

\footnotetext{
10 The first meeting of the Linguistic Society of America I attended was at Hartford, Connecticut in 1960, when I was interviewed for a teaching position at Hartford Seminary Foundation, for which see below.

${ }^{11}$ We were serving (at an annual salary in 1957 of $\$ 2,010$ for a family of four) with the Mission Evangélique de l'Oubangui-Chari. Its denominational name in the United States was the Foreign Missionary Society of the Brethren Church, its headquarters being in Winona Lake, Indiana. Since independence both names have changed: Mission Evangélique des Frères and Grace Brethren Foreign Missions. A few boxes of archives are stored in the library of Grace College and Seminary in Winona Lake, all dating back to the 1940s; none exist in the Central African Republic.
} 
to speak Mbati, while slowly losing all strength in my legs because of what was later diagnosed as peripheral neuritis, the consequence of taking Aralen, an antimalarial medication. Although I had learned from Pike something about 'tonal perturbation,' as Pike called it (later, tone displacement), I could not figure out why Mbati's tones did not stay put. (Many of the secrets of Africa's tones have subsequently been revealed, thanks to the work of generative phonologists, but anticipated, I think, by H. A. Gleason, Jr. [Gleason 1959].) ${ }^{12}$

The rest of my missionary career (1952-1960) can be characterized as a dedication to mastering and using Gbeya (the local pronunciation of Gbaya) and to teaching people how to read in Sango according to scientific principles we had learned at SIL's summer institutes. (My predecessors had used only the New Testament in teaching literacy.) While practically paralyzed in the legs, I boldly asked Field Council to appoint us to a district where we could work in an ethnic language. Bossangoa, it turned out to be, where the mission had been founded in the $1920 \mathrm{~s}$ by a couple now near retirement. ${ }^{13}$ Using Sango as my link with Gbeya, I began learning the latter in 1954, having regained my health after two months of intensive medical treatment. (Sango, although a pidgin, is enough of a Ubangian language to be a sort of key to the structures of indigenous ethnic languages.)

The study of language and everything else, of course, was extracurricular, since I was responsible for a district of about 80,000 persons, most of whom spoke Gbeya in one form or another. But how else could you learn to know a people among whom you expected to spend your whole life without learning something about their personal names, their dog-names, the names of villages and creeks, their riddles and proverbs, their sorghum-pounding songs? And all of this, first, without a tape-recorder, and then with one that drew a lot of power from the truck's battery. (Our only good source of light in the house was a Coleman kerosene pressure lamp.) While on a field trip on one occasion I depleted the battery's power. About twenty villagers pushed my pick-up to get it going again. The recorder was therefore used only on special occasions and only for recording. My first tapes being magnetized paper ones, they would in any case probably not have survived repetitive use. (In spite of the difficulties I have samples of Sango from 1957 and 1958.)

Although linguistics (as I conceived it as a missionary) was extracurricular, as far as my role and my responsibilities were concerned, I had arrived in Africa with the resolution to write an article a year. Little did I know about how hard life in Africa would be! How optimistic I

${ }^{12}$ In this careful review and survey of several things that had recently been discovered Gleason notes the "need for better theory" for dealing with tone, adding, "development of a theory better able to handle tone will result automatically in better theory for all phonologic subsystems" (1959:302).

${ }^{13}$ Chauncey and Hattie Sheldon, like all their co-workers in the $1920 \mathrm{~s}$ and $1930 \mathrm{~s}$, learned what they called the tribal language. Like the others, all without any kind of linguistic training, they failed to understand some aspects of the phonology and especially the importance of tone. However, this is not for not having tried. They corresponded with Edward Sapir. The correspondence does not seem to have been preserved, but they gave me a copy of Jespersen's Language (1921) when they retired, which Sapir had recommended to them. Curiously, it is Hattie's name that is inscribed as being the owner of the book. 
was of the possibilities of publishing what I wrote! The ingenuousness and naiveté of a zealous undergraduate! It was not possible for me to adopt a schedule of writing, nor did I even consider such. However, when I became a scholar I set aside one day a week, usually Monday or Friday, for writing. So disciplined was I in the writing of Tongues of Men and Angels (1972a) that I even logged myself in and out throughout an eight-hour work day. Although the record is lost, I recall having spent ninety hours in completing the first draft, a fact, if it is that, that surprises even me.

My Gbeya assistant was Gédéon Gounte, blind from meningitis since the age of fourteeen. From six kilometers away he came from Gbazian, all by himself, down the dirt road, five days a week and always on time. (We eventually became relatives when I contributed to the bride-price of the wife he acquired.) One hour a day with Gounte and a whole day using Gbeya (a small spiral notebook and mechanical pencil always in the hip pocket of my khaki shorts) provided me with enough to do at night. This was at the time when linguistic files consisted of innumerable paper slips (today's computerized data base) illustrating every kind of variable in the language, all written by hand. This labor-intensive aspect of linguistic analysis had to be accompanied by vigilant measures to safeguard the data from fire, termites, and mice. Only later did I learn from H. A. Gleason, Jr. about the use of a mimeographing machine to produce multiple copies of data for analysis (Samarin 1967). In my study (a small structure made of sun-dried blocks and thatched with grass that had been my predecessor's tool shed), which also served as a bookstore during the day, I had the pressure lamp; inside the house, my wife read by a wick lantern: here is a né with high tone, and here is one with low tone; example after example was recorded and filed vertically in sections carefully labelled with the hope that a rule or pattern would be identified. Sometimes I was joined by 'I don't have a head with which to carry my in-laws' firewood,' (tan wèn yoo ne gíwá kó foo kóm bó ná) as that long insect with a tiny head is called in Gbeya. It seemed to observe my work from its perch on my typewriter. And there was no background music on tape or disk, but the trills of cicadae, the calls of night-birds, the shrill piping of hundreds of toads in the nearby stream, the shrieks of fruit bats in the mango trees, the beat of distant drums at some funeral wake at Kakada or Bodigi Bea - sounds that are recollected to this very day with exquisite nostalgia.

Notwithstanding our commitment for life to serve in Oubangui-Chari, given the poor health my wife was experiencing, I decided to get a degree in linguistics by way of 'insurance.' (I still felt too much of a foreigner in 'American' society for the pastoral ministry.) Since I was a native to Southern California, I considered studying at the University of California at Los Angeles (UCLA). The only linguist of the kind I was interested in studying with was Harry Hoijer, and he was in the Department of Anthropology. From him I got the impression that I would have to study more anthropology than I wanted. Besides, I would be too close to home: by marrying someone who was not of Russian birth I had alienated myself from my family, but my wife's parents lived in the Bay Area. The only person in Berkeley I consulted besides Emeneau was William Bright, who had received his doctorate and was on his way to India as a Fullbright Scholar. However, he was not responsible for my deciding on Berkeley, where I spent the year 1955-1956, during which I finished all graduate course requirements. (Emeneau advised me against working for the M.A. degree, giving my age as a factor.) I was taught by Murray Emeneau, Douglas Chretien, Madison Beeler, and Yakov Malkiel in four courses that might be 
considered linguistic. (The latter awed me by his lecturing in a two-hour seminar on Romance Philology without notes, and, had it not been for the custodian who came to lock the building, we would certainly have had to listen beyond the hour of 22:00! (For an interview with Malkiel see Kaye 1994.)

Linguistics had by 1955 become more exciting, and even more so when I returned in 1960, having given up missionary work because of my wife's chronic poor health, eventually diagnosed as metabolic stress to life in the tropics. My doctoral dissertation was a grammar of Gbeya. No one to my recollection suggested anything else but a grammar of a language based on field work. For me it was either Gbeya or Sango, and I thought that Sango was not complex enough for a dissertation. Although the tremors of the 'revolution' that would 'destroy' descriptive linguistics were already felt at Berkeley, I could not participate on one side or the other: I had a sick wife and two young children to care of and a job to find when our missionary allowance terminated in 1961. Besides, I had already done most of the analysis for the grammar of Gbeya in Africa. Not one of my professors suggested what kind of a grammar I should write. Nor did any member of my committee make demands or give suggestions about the way the grammar should be written. Indeed, I can recall only a single challenge while the dissertation was being examined in its preliminary form. David Olmsted, as I recall, did not approve of my introducing variation into my grammar. It gave me some concern, it should be noted in view of later developments in linguistics and later research of my own, that the way we wrote grammars then did not account for the kind of variation I found in the 'language' for which I was writing a grammar. Most grammars, it seemed to me then, had been based on work with only one informant or at least with only one variety of a language. (American linguistics was politely criticized in this regard by a Dutch linguist, whose field work had been done in Indonesia, when I was a visiting professor at the University of Leiden in 1966-1967.) I do not know that I had a particular grammar as a model. Given my training and my reading since 1947, it is understandable that I should have written as others did. I suspect, however, that Nida's Morphology had more influence on me than any other single work; it provided, one should remember, an outline of what a grammar might look like.

During this time, in need of some income, I was employed part-time on a child-language project directed by Susan Ervin (later Ervin-Tripp), whose principal assistant was Wick Miller. I transcribed tape-recordings of sessions Miller had with a child acquiring language (Miller and Tripp 1964). (Students in linguistics do not do enough language transcribing, a tedious task that is extremely rewarding.) We students organized our own seminars. I remember a review by Wick Miller of something 'new' called psycholinguistics. My other contemporaries were Karl V. Teeter (who taught at Harvard), William Shipley (University of California at Santa Cruz), Harvey Pitkin (at Columbia), Cathy Callahan (Ohio State University), Shirley Silver (Sonoma State), Robert Oswalt, Philip (otherwise known as Mohammed Ali Rahman) Barker (McGill University and the University of Minnesota), and William H. Jacobsen, Jr:; Miller taught at the University of Utah. Sydney Lamb, the slender young man with a very low voice whose speech was slow and distinct, was in one graduate course that I remember. On one occasion he asked a question of the teacher. The latter in my opinion appeared not to have an answer and bluffed his way through a response. I said to myself: "If I ever become a teacher, I will not do 
that. Deceit is worse than ignorance. I'll admit that I don't at the moment have the answer." Like others at 'Cal' (now referred to as UCB), Lamb's doctoral dissertation was on an Amerindian language, but he seems to have been more interested in what he called mechanolinguistics (Lamb 1958, 1961; see also Hill 1969:44). I remember his telling some of us in his calm, assured manner that the day would come when there would be hand-held automatic translators.

There was a Linguistic Circle (as I recall its name and the way it reverberated that of the Prague Circle) held in the homes of professors to which graduate students were invited. At one there was a report on the recently translated works of Hjelmslev $(1958,1961)$.

\section{Our 'Bloomfieldian' Heritage}

In reminiscing and reflecting on all that contributed to my formation as a linguist I cannot escape the feeling that nothing equalled in importance the eleven-week sessions of the Summer Institute of Linguistics in 1947 and 1951, and no single individual more than Nida both in person and in publications. Moreover, no single idea from my formative years (1947-1956) was more important than the one that determined the way we approached the study of language. It deserves special comment since it may contribute to understanding one feature of the difference between so-called Descriptive Linguistics and contemporary Theoretical (or Formal) Linguistics. I also associate with the linguistics of those years the appreciation for a certain style of writing, which it has always been my aim to emulate.

Each and every language, we were taught (I do not remember how nor by whom), had to be understood and described in its own terms. Other languages should not be cast into a mould of our own making. Even though we could not avoid using some of the grammatical terminology of the past, everything had to be defined in terms of the language under examination. It followed, but explicitly, that we did not in a DESCRIPTIVE GRAMMAR compare what the language had or did not have with respect to other languages. Description had to be uncontaminated by other tasks: such as comparative and typological studies.

There was something noble in this attitude toward other languages, something quite like our contemporary concern with the rights of women, children, and the handicapped. Not that other languages were powerless (although as a matter of fact we were studying preliterate languages for the most part), but that they had their own inviolable integrity.

If that was the premise that motivated the way we worked, what guides students today? Someone comes to me with questions about "WH-words" in Gbeya. I tell her that there aren't any, just ie 'where?' and other noun phrases containing ge 'what?' I'm being facetious, of course, for I go on to deliver her from consternation and teach her what someone else should have: that $W H$-word is an anglicist bit of jargon, an artifact of 'theoretical' linguistics, if not a cute phrase that was coined in the classroom at a time when continuity with the past was not an idée 
reçue, and discontinuity was celebrated in the Social Revolution of the $1960 \mathrm{~s}^{14}$

But the burden of my blues is not trivial. Although it is indisputable that a tremendous amount has been learned from the millions of hours of work devoted by thousands of men and women in the last three or four decades, there is a difference in the way language is perceived today. For many, it seems to me, language is an object - like a rat - in a laboratory. Students are taught what might be called Experimental Linguistics even as students are taught Experimental Psychology. This is not to suggest that experimentation is bad (after all, we experimented through elicitation in the descriptive era); indeed, given certain goals (like trying to establish what all or most languages of the world have in common), the fastest way to accomplish them is to proceed with certain methods. Of course, today's goals are vastly different from the ones to which my contemporaries and I addressed ourselves. However, can we in our hard-earned sophistication ever regain some of that humility or modesty with which we came to the 'exotic languages' of the world? And are students being taught today that all instruments of research must be used with the care of a brain surgeon?

About writing I must be brief. First, the expository style of descriptive linguistics appealed to me, because it was in my bones. One reason I enjoyed reading Darwin's The Origin of Species, I believe, was that the language was crisp and clear. Another Englishman whom I was reading in the 1940 s was C. S. Lewis. His argumentation, although dealing with philosophical and theological matters, was similar. I am happy that long before I read Aristotle's Rhetoric (see 3.12) I had discovered that one of the first requirements of exposition is clarity. (I remember getting back a term-paper on which had been written next to the grade ' $\mathrm{A}$ ' a one-word comment: Clear.) The arrogance of students whose other teachers were less demanding than I was always an exasperation. How many of them demanded that they be graded for 'content,' not 'style'! I could have saved myself a great deal of trouble by obliging them to read Aristotle on this matter (3.1). Although I considered a course in writing inappropriate as a bonafide graduate course in linguistics, I did offer on a few occasions what I called Critique of Linguistic Description, in which students were taught not only how to write different genres but also how to read critically. Learning of this interest of mine, David Boynton, editor at Holt, Rinehart and Winston, invited me

${ }^{14}$ It appears to me that much in the culture of contemporary (and especially American) linguistics can be and should be studied in the context of its emergence during this apocalyptic period. Here I will cite only two trivial examples: the behavior of participants in scholarly conferences and the titles of journal articles. An example of the first is the stance of a young Ph.D. in the early 1960 s while giving his paper at an annual meeting of the Linguistic Society of America, when all sessions were plenary in a large hall: from time to time, in an aggressive gesture of nonchalance, he placed his left foot on a chair, standing directly before the audience, frequently placing the elbow of his left arm on the raised knee, his hand under his chin - an approximate replica of Rodin's 'The Thinker,' except that this fully dressed young man in this stance exposed his crotch. It must have been the vulgarity of the speaker's demeanor that made Adelaide Hahn, that grand old lady of Hittite studies seated a few rows ahead of me, to wince and crumple up her body in embarrassed confusion. In those days, incidentally, members of the LSA were still addressing each other as Mister and, I suppose, Madame. And I remember an occasion when K.L. Pike, who was chairing a session, gently tugged at a speaker's coattail to signal a deviation from proper procedure. In those days speakers, for example, did not field questions from the audience; they were addressed to the chair. It might not be unjust to suggest that the proletarianization of academia that began in that era has reduced the number of models of dignified decorum for emulation. 
to write a book on scholarly literature, but other fascinations preoccupied me. However, I did spend some time studying the written discourse of early sociolinguistics, a paper delivered (1979) but never tried to publish, for reasons I cannot recall.

\title{
The Linguist
}

In 1961 the River of Life flowed into a new bed. I turned down an invitation to join the linguists at the Foreign Service Institute of the Department of State in Washington, D.C. so as to be involved in teaching linguistics to career missionaries at the curiously named Hartford Seminary Foundation, where the departure of William E. Welmers for UCLA (the University of California at Los Angeles) had left a vacancy. To Gleason certainly goes the credit of having initiated the invitation; bibliophile that he is, he saw my apprentice's articles here and there. Although this was eight years after the publication of Gleason's exceedingly successful Introduction to Descriptive Linguistics, I had, however, heard little of him at 'Cal.'

Launched immediately in teaching courses at the graduate level, I became a professional linguist, a career which I accepted as a vocation. ${ }^{15}$ Now the journals to which I subscribed increased in number, revealing a preoccupation with Africa, subsequent subscriptions being ignored here:

\author{
Anthropological Linguistics, 1959 \\ African Language Studies, International African Institute, 1960 \\ Journal of African Languages, 1962 \\ Joumal of West African Languages, 1964 \\ American Anthropologist, 1963
}

What encouraged me in African studies at that time was becoming involved in the West African Language Survey, which Joseph Greenberg had instigated with the help of the Ford Foundation. Participation in my first conference in Dakar, 1962, was made possible by an all-expenses-paid trip arranged by Greenberg. ${ }^{16}$ At several such conferences I was to meet and become friends with a number of francophone colleagues; these friendships were maintained by rather frequent stop-overs or periods of residence in Paris. It was Greenberg also who invited me to give a paper (my first at a scholarly meeting) at the African Studies Association meeting in New York City in 1961. Linguistic research was significant in area studies programs after the enactment of the

\footnotetext{
15 A few years ago I was asked by Robert Le Page if I considered myself a linguist. The context, a short drive to where he was staying in Toronto, precluding a lengthy discussion, I answered with a simple yes. The answer might have been nuanced with words such as "Of some variety or other," and the like. Although he does not now remember that incident (personal communication, 4 May 1995), he believes that he might have been curious about what I took myself to be, given the fact that (to put it in my words) linguistics had become so sectarian (if not fundamentalist) that only if one believed and behaved in a certain way could one be considered a linguist. On this topic see also below.

16 The year 1962 seems to have been an active if not important one in my career. In addition to attending the conference in Dakar, I spent two months collecting data for my grammar of Sango (1967), participating in the conference on multilingualism in Africa in Brazzaville (Samarin 1962), and visited Africanist colleagues in Johannesburg, the consequence of having met Leonard Lanham at the 1960 meeting of the Linguistic Society of America in Hartford.
} 
National Defense Education Act. The ASA was one of the scholarly consequences of this act, and its annual meetings for several years featured sessions on language. For the meeting in 1969 I organized a session on Language and History, but I cannot remember why. Although my historical research on language and colonization had not yet begun, perhaps I was already thinking about African languages historically. I invited, among others, David Dalby, Christopher Ehret, and Johannes Fabian. The latter was a curious choice, because Fabian was not a linguist, but a social-cultural anthropologist. I had come to know him through his work on Jamaa, a Catholic, Swahili-speaking movement in Zaire, which had interested me because of my own work on language and religion (see Fabian 1970). He later gave a paper at a session of the annual meeting of the Society for the Scientific Study of Religion, of which I was a member for several years (Samarin 1971). Subsequently, language became important in his research and writing, adding a number of works to the literature on language and colonization (Fabian 1986).

It was a daunting experience to be a colleague of the only genuine genius I have ever known, Al Gleason. It was he who sent the agent of the publisher of his record-selling book to my office, to ask if I would be interested in writing a book about field methods in linguistics. Although the idea had never occurred to me, I told this representative that I would think about it. After recording ideas on slips of paper for a few months, I was surprised to see how many of them there were. Maybe I COULD write a book! And I wrote David Boynton of Holt, Rinehart and Winston to say that I would work on it.

It turned out being a book born too late. By 1967, the year of its appearance, the transformational-generative grammar movement (and it has to be characterized in sociological terms, see Murray 1994) led to a focussing on theoretical issues, and these were examined with languages most accesible to graduate students: usually, English. (The Massachusetts Institute of Technology [MIT] did not even offer a course in field methods; Terry Langendoen came all the way to Hartford to take that course.) Although Field Linguistics did not have sales to warrant being reprinted, I was invited in the 1970s by a different publisher to revise it, and again by another publisher in $1995 .{ }^{17}$ Someone else will have to write another book: I am too busy with Sango nowadays. Another book should be written, and it will be an entirely different one: field conditions are very different from what they used to be; linguistic concerns are multitudinous; and the new book will have to deal with the study of language contact, language variation, and many other topics comprehended loosely by the term sociolinguistics (as understood in descriptions such as those by Bright 1966, Ervin-Tripp 1971, and Grimshaw 1971).

Even before Field Linguistics was finished I had begun working on glossolalia in response to an invitation by Eugene Nida to publish something in collaboration with John Kildahl, a clinical psychologist. (Nothing came of the collaboration, for reasons that many collaborators

\footnotetext{
17 To the best of my knowledge the phrase field linguistics had never before been used as an equivalent for what was called (linguistic) field methods. It was while reading a book on archeology that I saw the phrase field archeology. At that moment the title of the book was chosen, for I saw a parallel in the working habits of archeologists and linguists (as I had known the latter). To what degree the phrase is now current, I do not know, but I have seen it here and there, most recently in Payne (1995:3).
} 
might understand. I published my first work in 1968, Kildahl in 1972, whose conclusions I disagreed with [Samarin 1972b].) The year 1965 is recognized as the watershed of the charismatic movement, newsworthy because it arose in some of the main-line Protestant churches and then in Catholic parishes and was characterized, theologically and empirically, by a linguistic phenomenon. I was asked by Christians what speaking in tongues was: a real language, some linguistic hoax, something satanic, and so forth. Here was an opportunity, I reflected, to do something both scholarly and popular. Without training in the methodologies of sociology and ethnology, I set about interviewing leaders and laypersons in the movement, engaged in participant observation in annual and regional meetings of the Full Gospel Business Men's Fellowship International, stood within two feet of Kathryn Kuhlman as she 'smote' people, as the religious jargon puts it, in healing (while observing her feminist lording over the fundamentalist, sexist male clergy ranked behind a long table on the dais at a mass meeting), had a private séance with a Cuban spiritist in Harlem, New York, and sat in the front row of a snake-handling, tongues-speaking church in Virginia. What fun! ${ }^{18}$

Other linguists in the Christian community besides myself were, of course, addressing themselves to glossolalia. In addition to Nida, the only other I know of, however, was William E. Welmers, who had written a letter to Christianity Today.

In researching and writing Tongues of Men and Angels I was continuing the kind of 'linguistics' I had been engaged in for quite some time, the kind of linguistics in which I had been trained by the kind of linguists my teachers had been. That some of what I was doing was now called sociolinguistics or anthropological linguistics was the consequence, not to simplify matters egregiously, of an emerging institutionalization of research which led to focussing on certain topics and creating an idiom for talking about them. The role of Dell Hymes in this regard is well known. Several of us from Hartford went to New York City to hear him give a paper at the Wenner-Gren Foundation on this new focus in linguistics and anthropology (Hymes 1963). What he did for me, quite early, I suppose, was to articulate things that I had felt all along. Our friendship and correspondence goes back many years. I was among his first consulting editors when Language in Society came into existence. It was in Rome, Italy, that Hymes talked about launching the journal with Joshua Fishman, John Gumperz, and myself, when we were participating in the International Days of Sociolinguistics (see International Days 1969).

At least one carfull of people also went regularly from Hartford to the meetings of the Yale Linguistic Club. Those who were fortunate enough to have Gleason as chauffeur got a free-ranging disquisition on linguistics, botany, mathematics, sectarianism, hymnody, typography, religion in India, the life and culture of Appalachian 'hill-billies,' among whom he had been a lay missionary before becoming a linguist, or any one of the other matters with which he was

\footnotetext{
${ }^{18}$ My own growing interest in the subject led me to suggest to Walt Wolfram that he write his M.A. thesis on "The sociolinguistics of glossolalia," which he did (1966). In retrospect, the title, for which I am responsible, embarrasses me Surely, the word sociolinguistics cannot be used in this way! Wolfram continued in sociolinguistics, where he has been ever since (and doing exceedingly well) having written his doctoral dissertation under my supervision based on research in Roger Shuy's project in Detroit (Wolfram 1969a, published as 1969b)
} 
phenomenally familiar - all the while going through parts of Connecticut unknown to any of the passengers or perhaps even Gleason, because he would never take the same way twice if he could avoid it. Devoted to students, Gleason, with my inexperienced assistance, launched the New England Linguistic Society, where graduate students read papers, and the Hartford Studies in Linguistics, in which were published the M.A. and Ph.D. theses of students at HSF.

Eventually it became clear to me that the practice of religion was, like other aspects of culture, impossible without significant uses of language, and I tried to interpret glossolalia in terms of anthropological linguistics. While still at Hartford I applied to the National Institute of Mental Health, for a grant to organize a conference on glossolalia. It was approved but not funded. In the 1960 s also I was invited to meet at Stanford University by Charles Ferguson to organize a conference on language and religion; Edgar Dimmock was the other participant. Nothing came of that meeting or Ferguson's proposal. Our paths have seemed to parallel each other over the years. Only in the case of the session on language and religion at a Georgetown Roundtable meeting did we actually work together (Samarin 1973, 1976; Roger Shuy was the editor of the series in which the latter volume was published). Nonetheless, the sociolinguistics of religion remains a largely untilled field in spite of the few papers Charles Ferguson also has written on the topic.

From the preceding review one might guess that during my seven years at Hartford, the first part of my academic career, I had not become personally involved in the linguistic revolution that was taking place. Already having been exposed to tagmemics in the SIL milieu, I learned what I could about TG theory. Because Gleason believed in exposing our students to every opportunity to learn something, a group of us from Hartford drove to Cambridge on one occasion to sit in on a seminar of Noam Chomsky's. (What I remember of it was his manner of repeatedly interjecting "OK?" as he went through his argument to an audience that said nary a word nor asked a single question). Gleason was working on stratificational grammar at Hartford, as was Sydney Lamb at Yale University). These novelties, however, were not sticky enough to catch this errant fly. ${ }^{19}$ This failure to become a card-carrying 'theoretical linguist' led occasionally to a feeling of marginality, I must confess, but I buoyed myself up with the realization that far too many things in language remained to be studied for me to feel guilty about not being involved in refining this or that part of ever-changing formal linguistics.

\section{Ideophones, for example.}

Like the pidgin I had learned, like glossolalia I had studied with all the seriousness I had addressed to any language, I undertook the study of another piece of flotsam on the linguistic seashore. Ideophones - descriptive adverbs in Gbeya - (a) constituted a major part of the lexicon of many African languages, (b) characterized Africa as a language area, and (c) played an important role in discourse and expressiveness. Nonetheless, Africanists had not taken them

\footnotetext{
${ }^{19}$ Indulging in a bit of psychohistorical esthetics, we might observe that I don't like to paint by numbers and prefer to create my own recipes. It's more exciting, more passionnant.
} 
seriously: Jan Voorhoeve once teasingly called me "Mr. Ideophone." Poor health interfered with the project that I had launched with a corpus of five thousand or more Gbeya ideophones, originally entered on hand-punched and then on machine-punched cards for computer analysis. This was a subject that could have become the passion of the rest of my life, a commitment that would have made me one of the fellowship of linguists now studying expressivity in language. And when I came back to the fork in the road, I decided to go right instead of left.

By this time I was at the University of Toronto, to which I had gone in 1968, when things were falling apart in Hartford but were coming together in Toronto, where the new Center for Linguistic Studies had just been established, of which Martin Joos was Director ${ }^{20} \mathrm{I}$ had, of course, looked everywhere in the United States for a job, but I wanted to go to a university with a graduate program and where I could continue my work in sociolinguistics. I even considered anthropology departments. Although it was not our original intention to remain permanently in Canada, failure to find a satisfactory alternative in the United States led by 1972 to our deciding to remain at the University of Toronto. Until the last few years there I had an appointment in the Departments of Linguistics and Anthropology, when my salary was divided between the two.

In the academic year 1968-1969 I had other things besides ideophones on my mind: it was then that I wrote Tongues of Men and Angels. Ideophones had followed the completion of that manuscript. Indeed, it was partly because of ideophones that I undertook the study of glossolalia, for I wanted to test my hypothesis that ideophonic stretches of speech would be found in that nonsense language. (I satisfied myself with a confirmation, but have not made anything of the fact in publication.)

In my first year of teaching undergraduates I introduced a course in sociolinguistics (a 'joint course' for my two departments), over the years offered under different guises: e.g., Language and Social Issues. The torch of sociolinguistics was taken up by Ronald Wardhaugh and J. K. Chambers, both of whom have published on this topic (1992 and 1995 repectively). I was never inclined to write a textbook about variation, but because I had not found a satisfactory text for Language in Culture and Society, which I offered in the Department of Anthroplogy, I began collecting material to write one. I gave up the idea simply because there was more fun in doing original (in my case, field) research.

But then I became a historian, which was not my intention at all. In 1972, after the book on glossolalia had been published, I made a deliberate choice one evening, while having a conversation with my wife, to return to African studies instead of going on with glossolalia. This meant, under the circumstances, the renewed study of Sango. It had already been inaugurated in the preceding year, when I went to Paris to study colonial archives. My original goal was only to write an article on the origin of Sango. I saw it as my obligation to contribute something on pidgin

\footnotetext{
${ }^{20}$ I consider it unfortunate to have known Joos only at the end of his life, when his eccentricities seemed to overshadow his magesterial intellect. He was magesterial, if not dictatorial, in some ways. On one occasion he told me that I should have my office door open. Well, since I never studied with an open door, not since childhood, I was not going to begin in 1969 !
} 
origins, a topic about which there had been a tremendous amount of speculation, most of it on languages based on European ones, whereas Sango was African. It was the conference on pidgin and creole languages organized by Dell Hymes in Jamaica, 1968, I suppose, that brought me into the vortex of pidgin and creole studies (see Hymes 1971). However, I had met a number of creolists at a conference in Brazzaville in 1962: David DeCamp, Fred Cassidy, Jan Voorhoeve, Robert Le Page, and others ....

.... 'Vortex'? Perhaps because I have worked only on an African pidgin, I have never to my knowledge been identified as a 'creolist.' Or is it because Sango is not the kind of language that can contribute to the search of the holy grail of Universal Grammar by following the clues of things like serial verbs and the development of tense-mood-aspect? Sango's serial verbs are patently substratal, and the language gets along very well, thank you, with hardly a nod to TMA. In any case, Derek Bickerton in 1975 excommunicated Sango from the discourse about what he calls pidgins and creoles, because, as he wrote to me, it is not a "plantation pidgin."

I became a historian, because there was no other way to account for the origin of Sango as a pidginized lingua franca than by studying colonization. The question I sought an answer for was simple enough: When and under what circumstances did any one of or several varieties of Ngbandi become a pidgin on the Ubangi River? It soon became clear to me that because there were so few Europeans (French and Belgian officers as well as Dutch traders) involved in the colonization of this area, it must have been the African employees of these whites who were involved in the creation of the pidgin. And that ended up being my conclusion about Kituba and Lingala as well as of Sango: in fact, they emerged out of one great pot-pourri of colonization at the end of the nineteenth century (1990/1991). The story of Sango has not yet been fully told, but out of this fifteen-year period of research issued The Black Man's Burden: African Colonial Labor on the Congo and Ubangi Rivers, 1880-1900.

Working with colonial, missionary, and personal archives in Africa, Europe, and North America gave me an appreciation for records I had never had before, making me remorseful about things I had given away, of the fire that destroyed some scholastic and personal records from childhood to about 1951, of my deliberately burning records and correspondence on leaving Africa in 1960 (to save the cost of shipping them to America!), and of the loss of at least one carton of professional correspondence and data in moving from Hartford to Toronto. On moving from one residence in 1987 I began creating at the Robarts Research Library of the University of Toronto a collection of material for future Africanists and historians of linguistics. On 1 May 1989, moreover, I began to keep a diary, which has evolved from a memoir of daily activities to a reflective journal of personal life and professional relevance. Although literacy is technologically easier in this computerized era, it is also inimical in some ways to the creation of archival treasures. I make hard-copies of electronic-mail messages, and I keep all the versions of the papers I write. If archeologists discriminatingly screen the rubbish of the past, is it not possible 
that my own midden might contribute a few artifacts to the history of linguistics? ${ }^{21}$

\section{Who am I? What am I?}

Early in my life, as I have already suggested, I was asking something like "Am I 'Russian' or 'American'?" Then I was asking myself "Am I a Molokan or a Protestant?" Later, different choices had to be made: dispensationalist; premilennarian; Brethren, Baptist, Presbyterian, or Anglican; fundamentalist, or evangelical, or just orthodox? To the secular person such choices are not only irrelevant to what is "really important" in life but even humorous, if not ridiculous. Was it a more serious question that the North American linguistic community led me to ask of myself? - who or what I was in it? Perhaps I have never stayed long enough in any particular area of scholarly concern to be labelled, although being considered a dilletante would be unjust. My assumption that some would not consider me a linguist was confirmed when I learned that one who had received her doctorate from the Massachussetts Institute of Technology reported to her parents, friends of ours, that I was definitely not a linguist. Perhaps I am a generic, No-Name brand of linguist.

The sectarianism revealed in this statement by a 'true believer' in linguistics is more than distasteful to me: it is repugnant. Having spent much of my life having to identify myself with respect to others in one kind of community and another, I find exclusionary attitudes detestable. I recognize, to be sure, that it is characteristically human (if not also characteristic of 'lower' creatures) to live in one or many spheres of 'us' and 'them.' If that is a primordial instinct, it is not to say that it is a civilized one.

If, then, $I$ have concerned myself with language in a scientific manner, contributing to this vast corpus of human knowlege, I am some kind of linguist. At one time I believed that I was a sociolinguistic variety of linguist, because I was engaged in research that was called sociolinguistic. William Bright must have recognized that when he invited me to participate in what may have been "the first conference to be exclusively devoted to this field" (Bright 1966:7) in May 1964 at a time when my work had been focussed mostly on Sango and I offered to write something on attitudes in the creation of diversity in that language (1966). I always thought I was engaged in "the systematic study of the relation of linguistic forms and social meaning," ErvinTripp's characterization of sociolinguistics (1971:15). Things have changed since then. Although one now advocates that sociolinguistics is concerned with "language variation and its social significance" (Chambers 1995:1), its "main theoretical construct" is "the linguistic variable" (Chambers 1995:2) ${ }^{22} \mathrm{Up}$ until recently I did not play around with the linguistic variable, but if quantitative data define the field of sociolinguistics (Labov 1995), I suppose my paper in 1964

${ }^{21}$ I believe so strongly in the importance of knowing the history of one's science that I would require every candidate for a doctorate in linguistics to take a course appropriate to the field. See also below.

22 According to my colleague at the University of Toronto "the heart of sociolinguistics since its inception more than three decades ago" is the "correlation of dependent linguistic variables with independent social variables" (Chambers 1995:xvii). 
qualified me for being a sociolinguist, because I interviewed twenty-seven subjects of both genders and various ethnicities with respect to thirty-five test items! But does any of this make a difference?

What DOES make a difference? . . . .

\section{A scholar's ethic}

No one among all of my teachers nor anything I ever read in linguistics taught me anything about the ethics of scholarship. Like everyone else in the linguistic community I brought into my professionalism something that I had inherited in character, something that I had learned at home and in the early years of school, and a lot that I inferred from observing the subculture of scholarship. What principles, then, have guided me, and what can I pass on?

I address myself to our behavior in the international community, realized partly in human interaction at conferences, symposia, workshops, and the like, but mostly through writing. Set aside for many reasons are matters that concern one's behavior as an employed person: a teacher and member of some institution. And of the fundamental virtues, like probity, nothing need be said: as light is to seeing, they are requisite for understanding. In decalogic fashion I suggest only four commandments.

\section{BE RESPONSIBLE.}

Scholars must convince others that they can be trusted when they make their arguments. By the very nature of scientific rhetoric this requirement is usually met. In a simple case, one describes one's data and what is revealed statistically. Since, however, reliability is gradient and sometimes even fuzzy, qualifications and hedges are sometimes required. There is, unfortunately, a vast area of greyness and obscurity in which we get lost or are misled. Shame on us when we exploit generally and frequently and usually when research cannot support our assertions! Would what we write stand up to examination when students are taught to challenge its veracity? 'Proof' can be a heavy burden to carry around; one's argument is always easier when it is simply put. Thus, it is simpler to declare that "Pidgins are characterized by ..." than to say that "From X, Y, and Z we observe that pidgins are ...."

\section{BE VULNERABLE.}

Everyone in scholarship has entered the ring. There is no escaping the pommeling we will experience, given to us in good will or ill. A colleague from another discipline described this kind of existence as masochism, and his manner revealed that it was not a masochism he enjoyed. (Is my case an odd one? I have frequently suffered painful symptoms of stress while simply disagreeing with the author whom I was reading!) One gets inured, we can tell our younger colleagues, to some of the criticism, justified or not, but it always helps to stay in training. Friends can help in preparing you for what may come 'out there.' For this reason I am grateful to all those who have read my manuscripts. I have also made it a practice, but not in every instance I must confess, of asking colleagues while still working on a paper if $I$ have understood them, if my criticism is just.

\section{BE CHARITABLE.}

We all make mistakes. We never know enough. We much too frequently express ourselves less 
clearly than we would like. This does not mean that we ignore imperfection, but that we deal with it in an understanding and forgiving manner. The most egregious example of the absence of this virtue, realized as an act of hubris, followed a statement made by Gillian Sankoff in discussing a paper at the International Conference on Pidgins and Creoles in Hawai' $i, 1975) .{ }^{23}$ She had barely begun to sit down when someone near me jumped up and exclaimed,

\section{Bull shit!}

With this proem he proceded with his argument. This reminds me of the time Bernard Bloch broke into his graduate student's presentation at a meeting of the Linguistic Society of America to say, "Go ahead and pronounce it!" seeing that he was on the verge of articulating a starred Indo-European form.

\section{BE CONSIDERATE AND GRATEFUL.}

From young people you might expect it: they haven't grown up yet; they haven't learned their manners; they take us for granted - we're paid, they think, to do what we do. So we support their applications and write recommendations and continue doing so throughout our careers even when only a few express their appreciation. Presumptuousness among professionals is harder to explain. Our lives would be a lot more pleasant and our tasks lighter if we were polite with one another. Not aware of all my sins, I recognize nonetheless some of them. For example, I should have been in touch with my teachers from time to time. I failed to do so with a reason, but it was immoderate modesty: They would not be interested in what I was doing. I will here rectify another failure: Never expressing my gratefulness to those who put their trust in me. Emeneau, for example. When he informed me in 1956 that Latin was required for the $\mathrm{Ph} . \mathrm{D}$., I studied it on my own. In time I reported to him that I was reading Caesar. He took my word for it. Haas trusted me, and so did Nida, as I have noted, in giving me tasks to do.

It takes no courage to recommend these for inclusion in a code of ethics. For others that might at least be considered I do not have the courage. I hesitate taking on the role of academia's Savanarola, especially because certain activities, while not talked about, are commonly practiced. To me some are as unethical as plagiarism, others beneath the dignity of society's intellectual leaders.

\section{Continuing on}

On the threshold of my retirement I decided that I would simply continue what I had begun twenty years earlier: putting together a story about Sango, its origin and development over a period of one hundred years, so that now the variety in Bangui, the capital of the Central African Republic, is greatly different from what I had learned in 1952. Perhaps I will continue as long as I can in mining fascinating things about Sango and sharing them with others: "Look at what I have found!" Unfortunately, the constraints of scholarly decorum prevent me from revealing the pleasure I may have experienced on one occasion or another, like when an assistant pluralized the Sango demonstrative só 'this,' providing in áso 'these' an instance of language

\footnotetext{
${ }^{23}$ I follow Aristotle's definition of hubris: “... doing or saying things that cause shame to the victim, ... its cause is this: Men think that by ill-treating others they make their own superiority the greater" (1932:94). We hold nothing against that person: perhaps he subsequently suffered remorse; perhaps he apologized.
} 
change. I will not deny, however, that my behavior may reveal more enthusiasm than ordinarily exhibited by professionals at least in the delivery of papers. ${ }^{24}$

There is no sweeter sound to my ears than Sango or Gbeya. I would have been happy, I should think (in retrospect, of course), to spend my whole life in the country where they are spoken. That having been impossible, I can only find pleasure, when not there continuing my research, in having internal conversations in either one of these languages and in imagining myself in different contexts where I would be speaking them. My favorite scene is that of a group of us sitting around the small fire at night sharing anecdotes. Although this is primarily a male cluster, laughter of children and women from the perimeter in response to a humorous turn in the discussion, makes one aware that this is a communal event. All seems well with the world. It is a scene like that more than any idyllic seashore center of hedonism that brings me into serenity and peace.

But serenity and peace have not followed me all the days of my life. For that reason I am grateful for the eleven years spent in the Central African Republic. For that reason also I have not been the institutional linguist I might have been. Apart from giving papers and organizing sessions at scholarly conferences I have not been involved in any academic organization at any level whatsoever. By the time I was nineteen the first symptoms of clinical depression and stress became evident. I was working too hard: carrying a full course of studies and working half-days at the Los Angeles Barber College on skid row toward the one thousand hours required for a barber's license in California. One might have thought that at least one of all the physicians I consulted over the years would have suggested a diagnosis of stress or depression, but none did, although all were willing to submit me to all kinds of tests for painful conditions of one sort or another, during which time Mephistopheles was at my elbow: "Wouldn't it be nice if you were in a fatal accident? or even suicide, perhaps?" Not until the very year of my retirement was medication prescribed that finally controlled depression.

A friend has suggested that my psychogenic problems result from a failure to resolve the contradiction between my being both a believer and a scientist. He is wrong. It is not, however, because of a lack of courage to express with candor what I believe is the diagnosis (for example, a genetic predisposition triggered by developmental history) but because this place is inappropriate. Suffice it to say that I find faith and foolishness in both science and religion. Here is an example of something that happened at a linguistic conference following the reading of a paper

\footnotetext{
24 At one meeting of the Linguistic Society of America my wife heard one person tell another, "Let's go hear Samarin. He's always good for a show." It should be noted, however, that because of my fear of interacting with other people in spoken language I took in high school a course in public speaking and even in salesmanship, where I was the only male student. In Bible school also I took the required course in homiletics. Some of this training may have helped me, but apparently not enough, because Russell Barnard, General Director of the Brethren missionary society, in writing to Orville D. Jobson, Field Superintendent in

Africa, said that I was "not too prominent" as a speaker, whereas my wife was "very excellent in this respect"! See Russell Barnard Archives at the Morgan Library of Grace College and Seminary, Winona Lake, Indiana, March 20 [dictated 10],1951.
} 
by Jane (the names here are fictitious):

Dick: "I take it then that if there is a word of five syllables [the following would happen with the tones]."

Jane: "Five-syllable words do not occur in my data."

The speaker's response was astute, but it circumvents what is surely a fact about the language, a variant of one that I speak. Its words are primarily mono- and disyllabic. Except for ideophones perhaps, it is almost inconceivable that a five-syllable word would occur. My point here is that this brief exchange was an artifact of a certain kind of linguistics. It would not have taken place long, long ago when Nida taught us in Morphology: the Descriptive Analysis of Words to make observations about what he called the canonical forms of words in a language. ${ }^{25}$

To whatever degree the hard sciences are self-validating, the same cannot be said of linguistics - at least the linguistics I have been involved in. This is an activity of disciplined curiousity characterized by skillful interpretation in which rhetoric is a tool as important as any other. Hypotheses are too frequently sown under the guise of conclusions; some operational terms have the fluidity and ambiguity of love and happiness.

At times I feel disheartened and cynical. Will it have been worthwhile to dedicate my life in the search of knowledge and understanding? A question like this struck me forcefully one day as I sat in the Bibliothèque Nationale in Paris. After hours of preparation, a stack of books finally piled up in front of me: my day's work. "What for? Who will care? Will it make any difference? Why strive for thoroughness if not perfection?" I looked around me at all the men and women, of all ages, from everywhere in the world; my eyes slowly scanned the thousands of volumes sedately standing on the shelves above me. "Who reads them today?" Who today reads any of what used to be the classics? Is the time-depth of our reading today only a decade? I seem to have been asking a question put by Goethe's 'author' in Faust:

Who wants to read, pray tell me, nowadays
A book that has a modicum of meaning?
As for the younger generation's ways,
They never were so pert and overweening!

The thought was not, however, devastating: I had set my hand to the plough; I persevered. We do not give up. We discountenance superficiality, foolishness, lack of seriousness, irresponsibility and the like as veniality that is more than compensated for by the excitement of searching for knowledge (if not truth), by the pleasure of finding (and in some sense creating) the beauty of things-as-they-are. If you do not share what I innovate in the kitchen or capture with my camera, you may find something in what I write. In this sphere of human activity all of us may pin our

\footnotetext{
${ }^{25}$ My response following that exchange, aroused by exasperation, was inexcusable: "Five-syllable words in this language are as likely as the rising of the sun in the west!"
} 
hope in what the hopeful 'poet' expressed, again, in Faust:

The brilliant passes, like the dew at morn;

The true endures, for ages yet unborn.

That, in any case, is the scholar's hope, for scholarship too is an endeavor of faith, hope, and charity.

\section{The End: Awards and Distinctions}

One is asked to list one's awards and distinctions in an official curriculum vitae or application for a research grant. Those are understandably appropriate places for recording them. But where else except in a memoirist chapter such as this can one bring into focus awards that are treasured invisibly in one's heart? And who else but those who understand more than others the nature of language and the role it plays in human relations would appreciate the honor of having received these awards? Linguists, to be sure. Yet not all of them, for it is not given by choice, chance, or circumstance to all linguists to earn these awards. The awards that an arm-chair or black-board linguist can anticipate are different, no less precious to be sure, from those serendipitously received by the field linguist, awarded not by a person of distinction, someone qualified to recognize and reward merit, but just a person of good will.

I write here of awards, not rewards. The latter I have already alluded to. My wife has told me, after I have made a comment of a linguistic nature having just heard or read something, "It doesn't take much to make you happy, does it?" Other rewards are richer and more memorable. If you have seen the full moon rising out of the deep sands that surround Timbuctoo dwarfing the sky as well as earth in its clarity and brilliance while you are drinking mint tea with some Tamachek-speaking 'Blue People,' you will have experienced some rewards beyond words and sharing. If you are sensitive to such beauty, of course. It is given to us who study language to have rewarding experiences, sometimes of simple pleasure, sometimes of 'spiritual' if not of almost transcendental significance.

I have just teased a young girl going the opposite way by remarking that whereas she had a parasol to protect herself from the sun, what could I do without one. About fifteen fect away from me she stops and says, Kà ga $m \dot{u} m \dot{a}$, and I am overwhelmed with information and sensations: I hear the first word in a construction where I wouldn't have expected it; I notice that she does not use the determinant $n i$ with the meaning 'it;' I enjoy the precise stepping up of pitch from low to mid to high and the abrupt falling to low again as she tells me, with no twinkle of coquetry on her lips, but with the spontaneous generosity of a well-reared African child: 'So come take it.' This is an imperishable and complex vignette. It illustrates the reward of being able to talk Sango and use it appropriately with another human being.

In my memory are stored untold numbers of such rewarding vignettes. For one who appreciates music but was never able to have a musical education, snatches of a sequence of pitch in Sango are relished as if they were classical melodies. William Welmers - a redoubtable analyst of tone, there is no doubt - used to boast of having perfect pitch. $I$, on the other hand, am evidence for all those 'with no musical ability' that learning to speak a language with tone is far from impossible 
or even difficult

Rewards, I say. "Risks?" you ask. Yes, there were, in addition to all the unpleasant and disagreeable aspects of living and working long hours in the tropics, dangers that one could anticipate: malaria (almost eradicated with DDT in the colonial era, now more rampant and more difficult to avoid and treat), filariasis, amoebic dysentery, hook worm, schistosomiasis (bilharzia), and other diseases. I've had my share: malaria too frequently and a debilitating case of schistosomiasis contracted in 1966 apparently but not diagnosed and treated until January 1974. But who would have thought that a small tape-recorder used while I was recording what boys said to each other in a game of marbles, deluged by the din of all the curious observers, would injure my hearing, depriving me forever of the ability to hear high-frequency sounds? All these, I say in sincerity, have not been too high a price to pay for the rewards and awards.

The awards, because they are fewer, are all the more precious. I cite only two:

- Ga ma nengo Sango tí mbùnzu só! A Central African civil servant who had every right to be bored at best or truculent at worst as she checks the visa in the passport cries out joyously to a fellow worker: 'Come listen to this white man's Sango!'

- Só álà tènè yanga tí kodoro tí $i$, ànzèrè nà mbi mingì. The secretary at a Central African bureau: 'It pleases me a lot that you talk our language.'

The award is not accepted by me as an honor of competence in the language of the Central African Republic. I know too well my limitations. Like all linguists, I know what 'knowing a language' means. It is enough that I have touched the hearts of others with their language. In 1994 while trying to help some Central Africans in teaching Peace Corps volunteers, I said, Yanga tí kodoro àkè kámbà só àkángà be tíázò àga ókò 'An indigenous (literally, village) language is rope that binds together people's hearts.' If someone in effect tells me, 'Well, you're bound to us,' I can have no better award as a linguist or as a human being. That kámbà 'medal' is worn with honor.

In that extemporaneous sincere declaration, adopted as the heraldic motto in this memoir's portrait (page XX), is a lovely irony for a person who consciously and falteringly had to learn the art of conversation in his own language and who, nonetheless, has felt the need for avoiding personal dialogue throughout most of his life. By learning foreign languages in a foreign context, he came to see language as a key to rich human encounters and relationships, and this to such a degree that in spite of his age (but perhaps also partly because of his age) he enjoys the marvels and mysteries of putting together sounds, words, and sentences so as to experience in isolated moments or over protracted periods of time with the same interlocutors some of the purposes to which language can be put in face-to-face interaction. This is because he has come to perceive language in an incarnational model: becoming like others by taking their language to 


\section{Résumé}

William John Samarin, b. February 7, 1926, Los Angeles, California, to John A. and Hazel J. (Kornoff). Educated up to high school in Los Angeles; B.Th., Bible Institute of Los Angeles (Biola, now Biola University), 1948; B.A., University of California at Berkeley, 1950; Ph.D., University of California at Berkeley, 1962. Career: Missionary-linguist, Central African Republic, 1951-1960; Professor of Linguistics, Hartford Seminary Foundation, Hartford, Connecticut (Assistant

Professor to Full Professor), 1961-1968; Professor of Linguistics, University of Toronto (Joint appointment in Departments of Anthropology and Linguistics; 1968-1985; Anthropology, 1985-1991; Professor Emeritus, 1991). Married to Ruth M. (Custer) Samarin, 1947; children, Manya Ivanne Egerton and Ramona Marie Furst.

${ }^{26}$ Although I was revising what I thought was a completed draft of this chapter, I profited from a conversation with George and Manya Egerton about memoirs, whose good counsel I wisely heeded. See Egerton 1994. Special thanks must go to Stephen $O$. Murray who commented most perceptively on all but the last version, asked me several good questions, and provided me with a transcript of an interview he tape-recorded in 1977, when he was researching his doctoral dissertation (now Murray 1994). Karl V. Teeter and Robert Le Page also kindly responded to my inquiries. The portrait is the work of the wood-engraver Nancy R. Jackson, of Mauricetown, New Jersey. 


\section{REFERENCES}

Aristotle. 1932. The Rhetoric of Aristotle. An expanded translation with commentary by Lane Cooper. New York: Meredith.

Bright, William. 1966. "Preface". Sociolinguistics ed. by W. Bright, 7. The Hague: Mouton.

Chambers, J. K. 1995. Sociolinguistic Theory: Linguistic Variation and its Social Significance. (Language in Society, 22.) Oxford \& Cambridge, Mass.: Blackwell.

Egerton, George. 1994. "The Politics of Memory: Form and Function in the History of Political Memoir from Antiquity to Modernity". Political Memoir: Essays on the Politics of Memory ed. by George Egerton, 1-27. London \& Portland: Frank Cass.

Emeneau, Murray B. 1994. "A Nova Scotian Becomes a Linguistic Indologist". First Person Singular II ed. by Konrad Koerner, 83-101. Amsterdam \& Philadelphia: John Benjamins.

Ervin-Tripp, Susan. 1971 [1969]. "Sociolinguistics". Advances in the Sociology of Language ed.

by Joshua A. Fishman, Vol. I, 15-91. The Hague: Mouton.

Fabian, Johannes. 1970. Jamaa: A Charismatic Movement in Katanga. Evanston, Ill.:

Northwestern University Press.

_- 1986. Language and Colonial Power: The Appropriation of Swahili in the Former Belgian Congo, 1880-1938. Berkeley: University of California Press.

Gleason, Henry Allan, Jr. 1955. An Introduction to Descriptive Linguistics. New York: Holt, Rinehart \& Winston.

- 1959. Review of The Role of Tone in the Structure of Sukuma by I. R. Richardson (London: School of Oriental and African Languages, University of London). Language 37:2.294-313.

- 1965. Linguistics and English Grammar. New York: Holt, Rinehart \& Winston.

Goethe, Johann Wolfgang. 1949. Faust. Part One. Translated by Philip Wayne. Harmondsworth: Penguin.

Grimshaw, Allen D. 1971. "Sociolinguistics". Advances in the Sociology of Language ed. by Joshua A. Fishman, Vol. 1, 92-151. The Hague: Mouton.

Hill, Archibald A., ed. 1969. Linguistics. Washington, D.C.: Voice of America, U.S. Information Agency.

Hjelmslev, Louis. 1953. Prolegomena to a Theory of Language. Translated by Francis J.

Whitfield. (Indiana University Publications in Anthropology and Linguistics, Memoir 7.)

Baltimore: Waverly Press. (2nd rev. ed., Madison: University of Wisconsin Press, 1961.) Homburger, Lilias. 1949. The Negro-African Languages. London: Routledge \& Kegan Paul. Hymes, Dell. 1962. "The Ethnography of Communication". Anthropology and Human Behavior ed. by Thomas Gladwin \& William C. Sturtevant, 13-53. Washington, D.C.: Anthropological Society of Washington.

_- 1963. "A Perspective for Linguistic Anthropology". Paper read on 19 January 1963 at a Wenner-Gren Supper Conference, Wenner-Gren Foundation Headquarters, East 71st Street, New York City.

-, ed. 1971. Pidgin and Creole Languages. Cambridge: Cambridge University Press. International Days of Sociolinguistics/Giornate internazionali di Sociolinguistica). Second

International Congress of Social Sciences of the Luigi Sturzo Institute. Rome: Luigi Sturzo Institute. 
Jespersen, Otto. 1921. Language: Its Nature, Development, and Origin. London: Allen \& Unwin; New York: Henry Holt \& Co.

Kaye, Alan S. 1993. "An Interview with Yakov Malkiel". Language Sciences 15:1.53-75.

_. 1994. "An Interview with Kenneth Pike". Current Anthropology 35.291- 298.

Kildahl, John P. 1972. The Psychology of Speaking in Tongues. New York: Harper \& Row. [See Samarin 1972b.]

Labov, William. 1972. "The Social Setting of Linguistic Change". Sociolinguistic Patterns by W.

Labov, 260-325. Philadelphia: University of Pennsylvania Press.

- 1995. Back-Cover endorsement of Chambers 1995.

Lamb, Sydney M. 1958. Mono Grammar. Ph.D. dissertation, University of California at Berkeley.

—. 1961. "The Digital Computer as an Aid in Linguistics". Language 37:3.382-412.

Merrifield, William R. 1958. "The Kiowa Verb Prefix". International Journal of American Linguistics 25:3.168-176.

Miller, Wick \& Susan Ervin. 1964. "The Development of Grammar in Child Language". The

Acquisition of Language, ed. by Ursula Bellugi \& Roger Brown, 9-34. Chicago: University of

Chicago Press.

Murdock, George Peter. 1946 [1934]. Our Primitive Contemporaries. New York: Macmillan.

Murray, Stephen O. 1994. Theory Groups and the Study of Language in North America: A Social History. Amsterdam \& Philadelphia: John Benjamins.

Nevin, Bruce E. 1992. "Zellig S. Harris: An Appreciation". California Linguistic Notes

23:2.60-64.

- 1993. "A Minimalist Program for Linguistics: The Work of Zellig Harris on Meaning and Information". Historiographia Linguistica 20:2/3.354-398.

Nida, Eugene A. 1949 [1946]. Morphology: The Descriptive Analysis of Words. Second and completely new edition. Ann Arbor: University of Michigan Press. (Repr. 1965, 1967, and 1970.)

- 1951. An Outline of Descriptive Syntax. Glendale, California: Summer Institute of Linguistics.

_ 1991. "My Linguistic Odyssey". First Person Singular II ed. by Konrad Koerner, 227.

238. Amsterdam \& Philadelphia: John Benjamins.

Oates, Joyce Carol. 1995. "American Gothic". The New Yorker, 8 May 1995, pp. 35-36.

Payne, David. 1995. "From the Linguistics Coordinator". Notes on Linguistics, Number 69, p. 3.

Pike, Kenneth L. 1948. Tone Languages. Ann Arbor: University of Michigan Press.

Pittman, Richard. 1953. A Grammar of Tetelcingo (Morelos) Nahuatl. Ph.D. dissertation,

University of Pennsylvania, Philadelphia.

Samarin, William J. 1952a. "Caution on Greek Connectives". The Bible Translator 2:3.131 132.

—. 1952b. "A Tentative Analysis of the Pluralization of Kisi Nouns". Kroeber

Anthropological Society Papers 5.48-84. Berkeley, California.

—. 1952c. "Intonation in Tone Languages". African Studies 11.80-82.

- 1962. "Une lingua franca africaine". Colloque sur le multilinguisme, 257-265. Brazzaville:

Commission de Coopération. [Translated by Charles Taber.]

—_. 1966a. "Self-Annulling Prestige Factors among Speakers of a Creole Language".

Sociolinguistics, ed. by W. Bright, 188-206. The Hague: Mouton. 
1966b. The Gbeya Language: Grammar, Texts, and Vocabularies. (University of California Publications in Linguistics, 44.) Berkeley \& Los Angeles: University of California Press.

- 1967. Field Linguistics: A Guide to Linguistic Field Work. New York: Holt, Rinehart \& Winston.

- 1968. "The Linguisticality of Glossolalia". The Hartford Quarterly 8:4.48-75. Hartford, Connecticut. [Hartford Seminary Foundation]

- 1971. Organizer and chairman, session on "The Sounds of Solemn Assemblies: A

Sociolinguistic Examination of Religion", Annual meeting of Society for the Scientific Study of Religion, Chicago, Illinois.

- 1972a. Tongues of Men and Angels: The Religious Language of Pentecostalism. New

York: Macmillan.

_ 1972b. Review of Kildahl (1972). Sisters Today 44:1.41-44. [St. John's Abbey,

Collegeville, Minnesota.]

- 1973. "Sociolinguistics and Religion: Report of interest-group session". Georgetown

University Monograph Series on Languages and Linguistics, 25.335-337. Washington D.C.:

Georgetown University Press.

- ed. 1976. Language in Religious Practice. Rowley, Mass.: Newbury House.

- 1979. "The Reason and Rhetoric of Sociolinguistics". Paper read at the University of Birmingham.

_ 1986. "Chinook Jargon and Pidgin Historiography". Canadian Journal of Anthropology

5.23-34.

- 1988. "Jargonization before Chinook Jargon". Anthropological Research Notes

22:2.219-238.

- 1989. The Black Man's Burden: African Colonial Labor on the Congo and Ubangi Rivers, 1880-1900. Boulder, Colorado: Westview Press.

- 1990/1991. "The Origins of Lingala and Kituba". Journal of African Languages and Linguistics 12.47-77.

- 1995. "Domesticity in the Development of Chinook Jargon". Language Contact in the

Arctic: Northern Pidgins and Contact Languages ed. by Ernst Håkon Jahr \& Ingvild Broch.

Berlin: Mouton de Gruyter.

Shipley, William, ed. 1988. In Honor of Mary Haas. Berlin: Mouton de Gruyter.

Waltke, Bruce K. 1993. "How I Changed My Mind about Teaching Hebrew (or Retained It)".

Crux 29:4.10-15. [Regent College, Vancouver, British Columbia.]

Wardhaugh, Ronald. 1992. An Introduction to Sociolinguistics. 2nd ed. Oxford: Basil Blackwell. Wolfram, Walt. 1966. The Sociolinguistics of Glossolalia. M.A. thesis, Hartford Seminary Foundation, Hartford, Connecticut.

- 1969a. Linguistic Correlates of Social Stratification in the Speech of Detroit Negroes.

$\mathrm{Ph}$.D. dissertation, Hartford Seminary Foundation, Hartford, Connecticut.

- 1969b. A Sociolinguistic Description of Detroit Negro Speech. (Urban Language Series, 5.) Washington, D.C.: Center for Applied Linguistics.

Young, Pauline V. 1932. The Pilgrims of Russian-Town: The Community of Spiritual Christian Jumpers in America. Chicago: University of Chicago Press. (Reprinted, New York: Russell \& Russell, 1967.) 